\title{
INVESTAVIMO AKCIJU RINKOJE NAUDOJANT GILIOJO MOKYMOSI MODELIUS TYRIMAS
}

\author{
Nijolè MAKNICKIENĖ, Amanda URBONAVIČIŪTE்* \\ Vilniaus Gedimino technikos universitetas, Verslo vadybos fakultetas, \\ Finansu inžinerijos katedra, Sauletekio al. 11, LT-10223, Vilnius, Lietuva \\ *El.paštas amanda.urbonaviciute@stud.vgtu.lt
}

\begin{abstract}
Santrauka. Kiekvienas investuotojas ieško geriausio sprendimo, taktikos ir metodo, kuris padètu pelningai nustatyti akcijų kainų judejjimo kryptis. Tačiau investuotojai susiduria su sunkumais nuspejjant akcijų kitimo kryptis. Dažnai pasirinktas ir naudojamas metodas nėra tikslus prognozavimo įrankis, todèl investuotoju dèmesys krypsta ị giliojo mokymosi metodus, kurie tampa paramos sistema investuotojui. Straipsnio tikslas yra palyginti giliojo mokymosi ir techninès analizès metodo prognozes bei akcijų kainų krypties nuspejjamumo paklaidas. Ištyrus penkių pasirinktų akcijų kainų prognozes gautas giliojo mokymosi metodo prognozavimo pranašumas lyginant su slankiojo vidurkio metodu. Šio darbo rezultatai išlieka svarbūs ir aktualūs, nes tyrimai susiję su giliojo mokymosi metodo panaudojimu investavime atskleidia galimybes investuotojui ar spekuliantui.
\end{abstract}

Reikšminiai žodžiai: akcijų rinka, prognozavimas, investavimas, gilusis mokymasis, techninè analizè, akcijų kaina, paramos sistema.

\section{Ivadas}

Finansų rinkose ịvyko daug svarbių pokyčių, kurie pakeitė insvestuotojų elgesį, rinkas bei jų prognozavimo modelius, kaip finansinès krizès, ekonominiai ir politiniai pokyčiai, globalizacija bei vis besikeičiančiu finansiniu technologijų spartumas. Todèl finansų rinkoje vykstantys procesai tampa labai aktualūs finansų pasaulyje besisukantiems investuotojams, ekonomistams ir netgi mokslininkams. Finansų rinkose siekiama surasti ir pritaikyti tokị metodą, kuris padètų nustatyti tikslesnes investavimo prognozes bei akcijų kainas.

Esami prognozavimo metodai nèra pakankamai tikslūs, sunku nuspèti akcijų rinkos kainas ir jų kitimo kryptị. Todèl kyla problema, kaip surasti ir pritaikyti metodą, kuris rodytu tiksliausią kainų kitimo kryptị bei prognozes. Šiuo metu investavime yra plačiai taikomi techninès analizès metodai. Techninèje analizèje yra nagrinèjami istoriniai akcijų kainų duomenys, pagal kuriuos spèjama ateities akcijų kaina. Procesą palengvina naudojami prognozavimo indikatoriniai, kaip: slankiojo vidurkio indikatorius ir jo atmainos. Besikeičiančiame finansu pasaulyje vis ieškoma naujų būdų bei inovatyvių technologijų, kurias būtų galima pritaikyti tokioje srityje, kaip investavimas. Didelio susidomėjimo sulaukia dirbtinio intelekto, giliojo mokymosi (angl. deep learning) metodų pritaikymas ir investavime. Investavimo srityje dirbtinio intelekto tyrimai tampa labai perspektyvūs.

Tyrimo objektas - akcijų rinka.

Tyrimo tikslas - palyginti giliojo mokymosi algoritmo akcijų kainų prognozes su techninès analizès indikatoriaus prognozèmis.

Uždaviniai tikslui pasiekti:

1. Išnagrinèti mokslinę literatūrą apie akcijų rinkos prognozavimo metodus;

2. Prognozuoti pasirinktų įmonių akcijų kainas naudojant techninès analizès metodą remiantis pasirinktais indikatoriais;

3. Nustatyti pasirinktų įmonių akcijų kainų kitimą pritaikant giliojo mokymosi metodą;

4. Išnagrinejjus techninès analizès metodus, nustatyti, kuris metodas parodè tiksliausią akcijos kainą pasirinktose įmonėse bei palyginti techninès analizès ir giliojo mokymosi metodų akcijų kitimo kryptis.

Tyrimo metodai. Išsikeltam tikslui pasiekti ir uždaviniams įvykdyti taikomi atliktos analizės interpretavimo vertinimas, t. y. surinktos informacijos palyginimas, susisteminimas, interpretavimas. Akcijų kainu prognozavimui techninès analizès būdu bei giliojo mokymosi metodu naudojami Yahoo Finance (2019) internetinio tinklapio duomenys. Nustatant tiksliausią akcijų kainų prognozavimo metodą naudojama statistinè bei grafinè gautu duomenų lyginamoji analizè. 


\section{Investavimo akcijų rinkose metodų naudojimas: mokslinès literatūros analizè}

Sparčiai besikeičiantys finansiniai procesai skatina ieškoti naujų būdų kaip padidinti turimas pajamas. Didelio susidomejimo sulaukia finansų rinkų aktyvumas bei jų likvidumas. Finansų rinka suprantama kaip lèšų ar finansinių priemonių judèjimas ten, kur būtų galimas efektyvesnis jų panaudojimas tolimesniems finansiniams veiksmams, kaip kapitalo didinimui ar investavimui (Pekarskienè ir Pridotkiené, 2010). Finansiniai procesai susiję su rizikomis, kurių dažniausiai suvaldyti neimanoma, nes rizika priklauso nuo aplinkos pasikeitimų, kurie vyksta itin sparčiai. Finansų rinką įtakoja tokie pokyčiai kaip: ekonominiai ir politiniai veiksniai, kurie gali apsukti rinkas kita kryptimi (Bikas ir Kavaliauskas, 2010), todèl yra labai naudinga turèti savą supratimą, kad būtų galima pasirinkti atitinkamą sprendimą, net ir asmeniškai.

Akcijų rinka yra viena iš svarbiausių finansų rinkų, pagal kurią galima matyti esamą ir net nuspèti būsimą ekonominę situaciją. Pavyzdžiui, jei ekonomika auga, tai ir akcijų rodikliai palankūs, jei akcijos krenta, tai reiškia, kad ekonomika ims lètèti (Cibulskienè ir Marcišauskienè, 2013). Glaudus akcijų ir ekonomikos pasikeitimų ryšys matomas vykstant didžiausioms finansų krizèms, kaip Pirmoji pasaulio krizè, Pasaulio krizé, Tarptautine finansu krizè, Didžioji depresija, 2008 metu globali krize kt. Finansų krizès labai paliečia ir finansų rinkas, kadangi prekiaujama vertybiniais popieriais (akcijomis), kuriuose slypi dideli kiekiai pinigu (Mockaitienè ir Žmiejauskaite, 2009). Akcijų rinka laikoma viena iš rizikingiausių, bet tuo pačiu galinčių atnešti didelę investicinę grąžą. Dèl to įmonès, norèdamos pritraukti reikalingą kapitalą iš potencialių investuotojų renkasi akcijų rinką. Akcijos suteikia galimybę paskirstyti lěšas tarp skirtingų subjektų, tokiu būdu valstybès ar įmonės gali papildyti savo biudžetą lěšomis, taip pat investuotojai gali investuoti i laisvas lěšas tikèdamiesi pelno ateityje (Cibulskienè ir Marcišauskienè, 2013). Kiekvienas dalyvis ị rinką ateina su nustatyta, pradine akcijos kaina. Akcijų kaina yra nuolatos kintanti, kadangi akcijų rinka yra labai aktyvi ir veikianti visą laiką, dėl to per trumpą laiką kaina gali labai greitai išaugti nuo neigiamos iki aukštos. Gera ekonominè situacija, augančios bendrovès, geri finansiniai rodikliai skatina rinkos dalyvius investuoti $\mathfrak{i}$ akcijas (Boreika ir Pilinkus, 2009). Tikroji akcijų vertė turètų atspindèti visą informaciją, kuri yra svarbi tos akcijos veikimui ir dèl tos priežasties turètų būti mažai įtakojama kitų sprendimų. Tai skatina kurti naujas, individualias schemas suprantant investavimo techniką bei taikyti individualius veiksmus asmeniškai, taip akcijų rinkose išlaikant balansą. Mokslininkų teigimu, tai priklauso nuo esamos pasiūlos ir paklausos, ekonominių, politinių pasikeitimų, bet kartais sunku nuspèti ateitị pažiūrẻjus ị dabarties akcijos kainas, todèl didelis investuotojų dèmesys krypsta ị akcijų indeksus, kadangi akcijų indeksai parodo akcijų rinkos situaciją ir vystimąsi bei kitimo tendencijas (Cibulskienè ir Marcišauskienė, 2013). Autoriaus teigimu, remiantis efektyvios rinkos hipoteze, buvusios akcijų kainų grąžos neturètų daryti jokios įtakos esamoms ir būsimoms akcijų kainų grąžoms, nors ir mokslinèje litratūroje gausu sẻkmingų investavimų istorijų, kurie remèsi akcijų praeities duomenimis (Gang et al., 2019). Vis dèlto akcijų indeksai yra skirti kiekybiniais būdais ịvertinti akcijų rinkų pokyčius. Remiantis akcijų indeksų pokyčiais, analizuojant akcijų indeksų istoriją, galima palyginti ir apskaičiuoti kitimo priežastis, tendencijas. Tiriant praeities ir darbarties akcijų kainų kitimus galima nuspèti ateities preminaliarias vertybinių popieriu kainas, jų kilimo galimybes bei akcijos pirkimo ar pardavimo laikotarpi, kuris atneštų didžiausią investicinę grązzą (Lileikienè ir Derviniené, 2010). Investuojant ị akcijas, nei vienas investuojas nèra apsaugotas nuo gresiančios rizikos neuždirbti pelno arba prarasti visą kapitalą, kadangi didelę grąžą visada lydi didelè rizika.

Investavimas akcijų rinkose pritraukia vis daugiau naujų finansų rinkų žaidejų . Svarbiausiu klausimu ir iššñkiu išlieka, kaip nustatyti akcijų rinkų kainų prognozes, kadangi akcijų kainų pokyčiai vis dar laikomi sunkiai apibrěžiami ir nepastovūs. Pagrindinès ir tradicinès akcijų kainų analizès metodu laikoma techninè analizè (angl. technical analysis). Dažnai investuotojai pasirenka ṣ̨̌ būdą akcijų kainoms analizuoti. Svarbia užduotimi ir tikslu tampa išsiaiškinti, kokia gali būti galutinè investavimo grąža (Kekyte ir Stasytytè, 2017). Techninès analizès analitikai tiki, kad dèl akcijos kainų chronologiško judèjimo judès panašia tendencija. Dèl to, analitikas norẻdamas prognozuoti akcijų kainų pokyčius, tiria tik istorinius kainų pokyčius nagrinėdamas diagramas, modelius ir daugybę rodiklių gautų iš atvirų, aukštų, žemų uždarymo kainų bei jų apimčių (Metghalchi et al., 2011). Taigi, techninės analizės metodu siekiama nustatyti akcijų kainų judejjimo tendencijas, jos pasikeitimo priežastis palyginant su ankstesniais etapais ir judèti tos linkmès pusèn. Techninès analizès pagrindinis tikslas yra ieškoti aukščiausiu bei žemiausių akcijos kainų taškų, kurie padètų tolimesnei analizei tarp akcijų kainų istorinių duomenų. Akcijų kainų svyravimai yra pasikartojantys, todèl techninès analizės grafikų naudojimasis padeda investuotojui nuspręsti, kada laikas pirkti, o kada reikia parduoti nenukenčiant finansiškai (Kekytè ir Stasytytė, 2017). Taip pat laikui bėgant buvo pastebèta techninès analizès modelio tobulèjimas. Kaip jau minèta anksčiau, šis metodas naudojamas akciju istorinès raidos analizei. Šiandien, pastarujų metų technologija leidžia naudoti realaus laiko duomenis nuspẻjant akcijų kainas. Investuotojai, vadovaujantis akcijų prekybos taisyklėmis, kuri paremta technine analize, naudojasi informacija pagrịsta indikatoriais, diagramų modeliais, kurie apima ekonometrinius, statistinius ir netgi dirbtinio intelekto modelius. Visa tai leidžia ịveikti akcijų rinką, kuri prieštarauja esamos rinkos hipotezei (Cervelló-Royo et al., 2015). Taip pat techninės analizės tyrejjai mano, kad šiuo būdu galima išsamiai paaiškinti rinkos pokyčius, kurių pagrịsta strategija yra pagrista akcijų kaina ir joje apskaičiuotais matematiniais rodikliais, kaip - slenkantis vidurkis - tendencijų nuspejjamumo matas, kuris parodo akcijų kainų laiko eilučių atliktą analizę (Picasso et al., 2019). Slenkančio vidurkio indikatoriaus tikslas yra nustatyti kainų pokyčiu tendencijas. Šis indikatorius parodo 
pirkimo ir pirkimo signalus, remiantis dviem slenkančiais akcijų kainų vidurkiais. Pavyzdžiui, akcijų kainų pirkimo signalas pasirodo tada, kai esama akcijų kaina yra aukščiau negu slenkančio vidurkio indikatoriaus, o pardavimo atvirkščiai, kai antrasis rodiklis pakyla aukščiau nei pirmasis (Sobreiro et al., 2016). O akcijų kainų vidurkị remiantis slenkančio vidurkio indikatoriumi apskaičiuojama pagal formulę:

$$
\operatorname{MA}(q)_{t}=\frac{1}{q} \times \sum_{i=t-q+1}^{t} p_{i}
$$

čia: $P$ - kaina laiko momentu $i$, o $M A(q)$ - slenkančio vidurkio vertė momentu $t$, apskaičiuota per paskutinius $q$ periodus.

Kiekvienos kainos svoris lygus $\frac{1}{q}$ (paprastai apibrèžiamas vidurkiu). Visa slenkančiojo vidurkio indikatoriaus esmė yra vadovautis pagrindine taisykle ,pirkti, kai kaina kerta slenkančio vidurkio rodikli iš apačios, o parduoti - kai kaina kerta slenkančio vidurkio indikatoriaus rodiklị iš viršaus“ (Kresta ir Franek, 2015). Tačiau techninès analizès naudojime pastebima ir trūkumų. Duomenų analize pagrịstos prognozès labai priklauso nuo subjektyvaus veiksnio. Tai reiškia, kad gauta informacija analizès metu, gali būti interpretuojama skirtingai. Techninès analizès naudojimas tampa vis mažiau populiarus, kadangi juo naudojantis labai didelei daliai aktyvių investuotojų ir didejjant procesų apimčiai, vien tik techninès analizès naudojimasis nėra pats tiksliausias akcijų kainų nustatymo įrankis dèl visuotinio populiarumo, metodų neapibrěžtumo (Nedzveckas ir Dapkus, 2013). Norint sumažinti riziką investavime, būtina pasinaudoti visais metodais, kurie padètų ją eliminuoti. Tačiau nèra paprasta tikslingai pritaikyti vieną iš metodų konkrečiai akcijų kainos analizei.

Pasauliui keičiantis ir tobulëjant, naujųjų technologijų atsiradimas ir jų naudingas pritaikymas įvairioms sritims sparčiai skatina domètis tokiomis technologijomis, kaip dirbtinis intelektas (angl. artificial intelegence). Kadangi, ši technologija, daugeliui asocijuojasi su tam tikrų procesų palengvinimu, pritaikomumu kasdieniniams ir rutininiams darbams, ši sritis laikoma labai perspektyvia. Dirbtinis intelektas jau stipriai pakeitè pramonės ir finansų pasaulį. Šiandieną visuomenè dirbtinị intelektą laiko ne vien tik technologija, kuri galbūt iš dalies galètų pagerinti procesų vykdymą, dirbtinis intelektas tampa būtinybe, be kurios neịsivaizduojamas našesnis ir produktyvesnis darbas, verslų kūrimas, tobulejjimas (Amilevičius, 2017). Dirbtinis intelektas apibrèžiamas, kaip sistema, kuri gali pati apsimokyti, savarankiškai prisitaikyti prie naujų pokyčių ar mokymosi. Todèl didelis dėmesys skiriamas giliajam mokymuisi, kadangi teigiama, kad:

- Intelektuali sistema turètų sugebėti spręsti problemas ir situacijas, kurios skiriasi nuo numatytų jos kūrèjų;

- Intelektinè sistema turètų gebėti apibendrinti ir įsisavinti igytas žinias, kad jas galètų taikyti ir kitokioms problemoms negu buvo apmokyta pirmiausiai.

Akivaizdu, kad bet kuri dirbtinio intelekto programinès įrangos sistema dẻl išvardintų savybių yra laikoma stipria pretendente turèti bendrą žmogaus intelektą (Goertzel, 2014). Gilusis mokymąsis suprantamas, kaip tam tikros sistemos savarankiškas gebejjimas pagal turimą, įdiegtą informaciją, taikyti naujus metodus modeliui treniruoti ir tada naudojant apmokytą modeli prognozems sudaryti iš naujų duomenų (Heaton et al., 2016). Giluminio mokymosi sistemos gali būti lengvai pritaikomos prie daugelio problemų, tiek teorinių ir praktinių, kaip: programų patobulinimas, našumo optimatizavimas, didelių duomenų apdorojimas, čia dirbtinis intelektas tampa plačiai naudojamas ir finansų srityje. Pavyzdžiui, investavimo srityje dirbtinị intelektą taiko nustatant sukčiavimo atvejus bei analizuojant finansų rinkų pokyčius bei tendencijas (Amilevičius, 2017). Tačiau pastebima, kad dirbtinio intelekto mokymosi programų taikymas investavime nèra pakankamai ištyrinèta sritis, kuri būtų taikoma investavime, todèl tai apsunkina investuotojams kainų rinkų nuspejjamumą, akcijų kilimo bei kritimo prognozes bei galimybę prekiaujant akcijomis užsidirbti. O vis didejjant akcijų kainų nustatymo sudètingumui ir tikslumui, investuotojai ieško būdų, kaip pereiti nuo ịprastų jau naudojamų akcijų kainų nustatymo metodų prie patobulintų strategijų, kurios padidintų investavimo pelną bei pačios rinkos prognozavimą (Naranjo ir Santos, 2019). Kadangi, investavimas finansų rinkose yra labai rizikinga sritis, kurią veikia daugelis ekonominių, politinių ar psichologinių veiksnių, mokslininkai ieško būdų, kaip palengvinti prekybą atliekant tyrimus bei kuriant investavimo modelius (Kekytè ir Stasytytè, 2017). Nauji modeliai ir dirbtinio intelekto taikymas finansų rinkose padètų ją suefektyvinti, sumažinant klaidų skaičių investuojant, įvertinti akcijų kainos pokyčių tendencijas, tačiau vis dar neaišku, kokią tikrają vertę ekonomikai galètų duoti dirbtinio intelekto naudojimas investavime. Jei sukurtos intelektualios sistemos veiktų tik investuotojo akcijų kainų prognozavimo naudai be rizikos, tai sukeltų neefektyvių lèšu pasiskirstymą tarp investuotojų bei akcijų prekiautojų. Prognozuojant akcijų kainas ar pačias finansų rinkas tai tampa didžiausiu iššūkiu dirbtinio intelekto kūrejams ir visai mokslininkų bendruomenei dèl dirbtinio intelekto galimybių pritaikymu investuojant. Taigi, apžvelgus naujausią literatūrą ir dirbtinio intelekto mokymosi metodus, nustatyta, kad neuroniai tinklai yra viena iš dominuojančių metodų akcijų rinkos kainų prognozavime (Al-Radaideh et al., 2013).

Vienas iš dirbtinio intelekto modelių, kuris gali būti taikomas investavime vadinamas - neuroniniai tinklai (angl. neural networks). Tai tinklai, kurie geba apdoroti duomenis naudojantis dirbtiniu intelektu, kuris sukurtas 
remiantis žmogaus neuroninių tinklų struktūra ir pagal nervų sistemos veikimo principą. Neuroninių tinklų veikimas pagrįstas neuronais, kurie apdoroja gautą informaciją. Signalai yra perduodami ryšių jungtimis. Jungtys turi atitinkamą svorị, kuris keliaujant signalais, priklausomai nuo informacijos gali padvigubėti, kitaip sakant, apsimokyti ir pritaikyti tam tikram sprendimui naują informaciją. Išvestinis signalas gaunamas naudojant jutimo vienetus, kurie sudaro įvesties sluoksnị, o ịvesties signalas aktyvinamas ị pagrindinį neuronų tinklą (Sureshkumar ir Elango, 2012). Taigi, tokiu būdu vyksta giluminis mokymąsis, todèl neuroninių tinklų pritaikomumas labai platus. Ankstesni tyrimai parodè, kad dirbtiniai neuroniniai tinklai yra tinkami naudoti modelio atpažinimui, duomenų klasifikavimo užduotims ir netiesioginiam, adaptyviam mokymuisi, todẻl plačiai taikoma analizuojant įvairius finansų srities duomenis. Dėl šių savybių, neurotinių tinklų metodas laikomas vienu svarbiausių sričių taikant akcijų kainų prognozavimui investavime. Rinkos žaidejjų elgesio modelio nustatymas ir akcijų kainų numatymas yra nauja neuroninių tinklų taikymo sritis. Daugelis kompanijų jau taiko neuroninius tinklus, kurie padètų pagerinti akcijų kainų prognozavimą analizuojant akcijų rinką (Sureshkumar ir Elango, 2012). Kadangi, neuroniniai tinklai veikia pagal koncepciją „,mokykis pagal pavyzdị“. Pavyzdžiui, dabartiniai akcijų kainų nuosmukiai ir pakilimai yra labai susiję su istoriniais praeities įvykiais, kurie įtakojo akcijų kainų pokyčius. Neuroniniai tinklai galètų modeliuoti tokius laikinus akcijų rinkų pokyčius, sukuriant giliojo mokymosi grižtamajj ryši (Vaisla et al., 2010). Dirbtinio intelekto nauji ar vis dar kuriami modeliai kaip neuroniai tinklai tampa vis svarbesni finansu rinkose. Dirbtinio intelekto programos galètų palengvinti tam tikrus procesus, jo pritaikomumu, patobulinti kasdieninius finansinius procesus padètų lengviau nuspèti bei suprasti akcijų kainų pokyčius, kitimo priežastis bei aplinkybes. Suvaldyti ir suprasti tokị didelị duomenų kiekį, globalų investuotojų srautą tampa vis sunkiau.

\section{Akcijų rinkos kainų krypties nustatymas naudojant techninę analizę ir giliojo mokymosi metodus}

Šiame darbe pasirinktos penkių įmonių akcijų kainos bus prognozuojamos naudojant paprastaji slankuji vidurkị ir giliojo mokymosi Matlab algoritmą laiko eilučiuc prognozavimui (Matlab algoritmas, 2019). Gautų rezultatų palyginimaas ir analizė leis atskleisti galimybes ir rizikas investuotojui.

Norint išanalizuoti tiksliausią akcijų kainų kryptị, daugelis investuotojų taiko technininèje analizèje naudojamus indikatorius, kurie padeda nustatyti tikslesnius nuosmukius, kilimus bei pačią akcijų kainų prognozuojamą kryptị. Remiantis autorių, kaip Angelès Lileikienès, Mindaugo Butko (Lileikienè ir Dervinienė, 2010), (Ginevičius ir Podvezko, 2008) ir kt. nagrinejjamą literatūrą tyrimui atlikti, pasirenkamas populiarus tarp investuotojų techninès analizès indikatorius, kaip slenkančio vidurkio indikatorius (angl. moving average).

Atliekant tyrimą, atsitiktiniu būdu pasirenkamos penkios bendrovès, kurios leidžia akcijas ir yra populiariausių sąraše:

1. APPLE - prekybos simbolis - APPL

2. TESLA - prekybos simbolis - TSLA

3. AMAZON - prekybos simbolis - AMZN

4. GOOGLE - prekybos simbolis - GOOG

5. NEFLIX - prekybos simbolis - NFLX

Tyrimui atlikti, pradiniai duomenys buvo gaunami iš internetinio portalo YAHOO FINANCE sudarant ir analizuojant grafikus bei juose pateikiamą informaciją pasinaudojant slenkančio vidurkio indikatoriumi dviejų metų laikotarpyje bei analizuojant trijų dienų akcijų kainų pokyčius, kurio metu buvo gauti tokie grafikai:

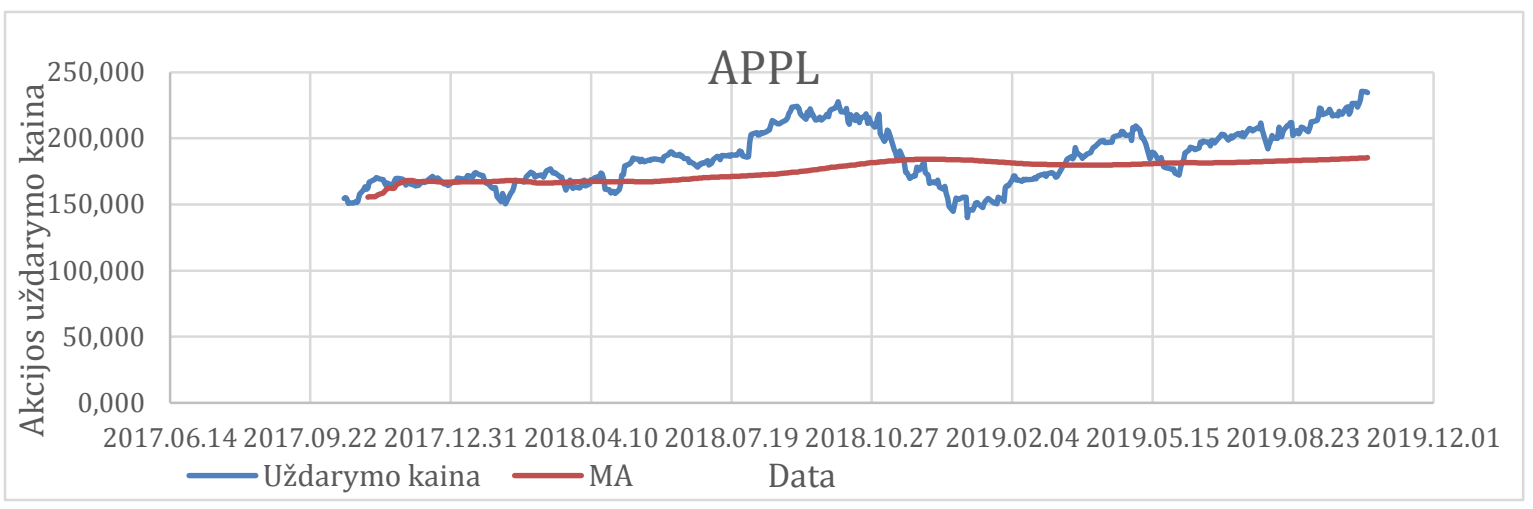

1 paveikslas. APPLE bendrovès akcijų kainų kitimas naudojant techninès analizès metodą (šaltinis: sudaryta darbo autorių remiantis www.finance.yahoo.com [2019.10.16] duomenimis) 
1 paveiksle naudojant statistinių duomenų analizę grafiškai matoma, kad slenkančio vidurkio linija yra žemiau negu istorinių duomenų susiformavus linija, tai rodo kaina kils, patikrinus kitos dienos pateiktą uždarymo kainą, uždarymo kaina kilo.

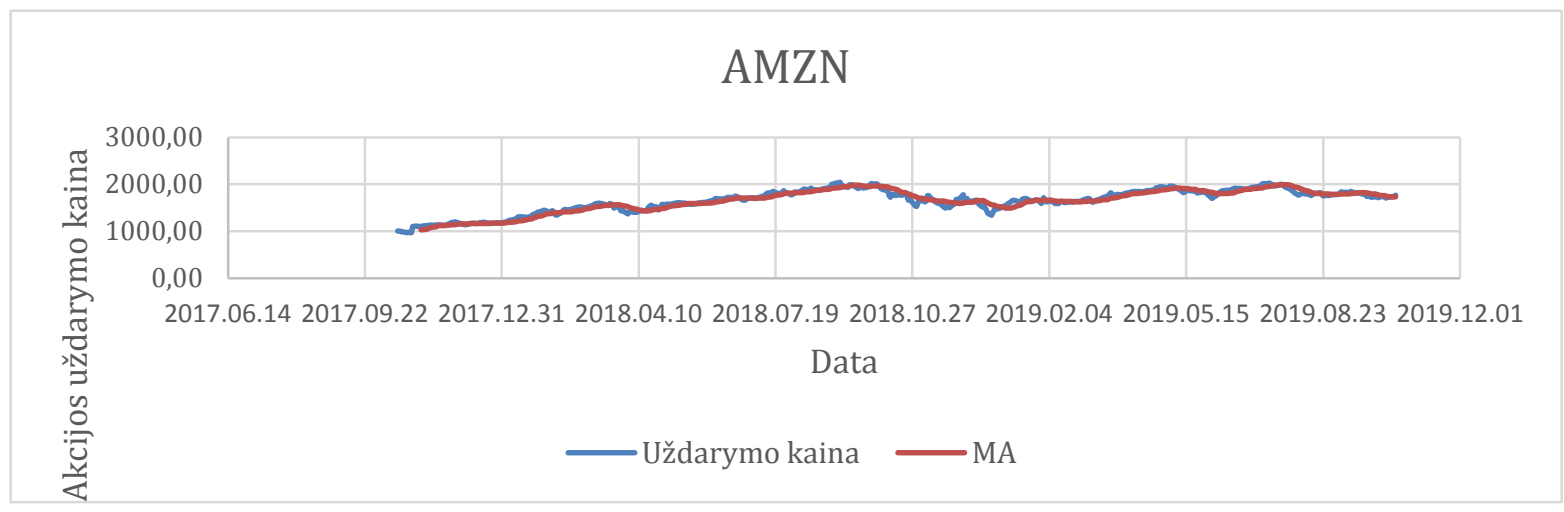

2 paveikslas. AMAZON bendrovės akcijų kainų kitimas naudojant techninės analizės metodą (šaltinis: sudaryta darbo autorių remiantis www.finance.yahoo.com [2019.10.16] duomenimis)

2 paveiksle matyti tolygus uždarymo kainos ir slenkančio vidurkio kitimas. Slenkančio vidurkio prognozė linija baigiasi ties uždarymo kainos linijos, t. y. nematomas aiškus kainos kritimas ar kilimas, tačiau stebint pačią prognozuojamą kryptị matomas kritimas. Nustatyta uždarymo kaina taip pat rodo mažejjimą.

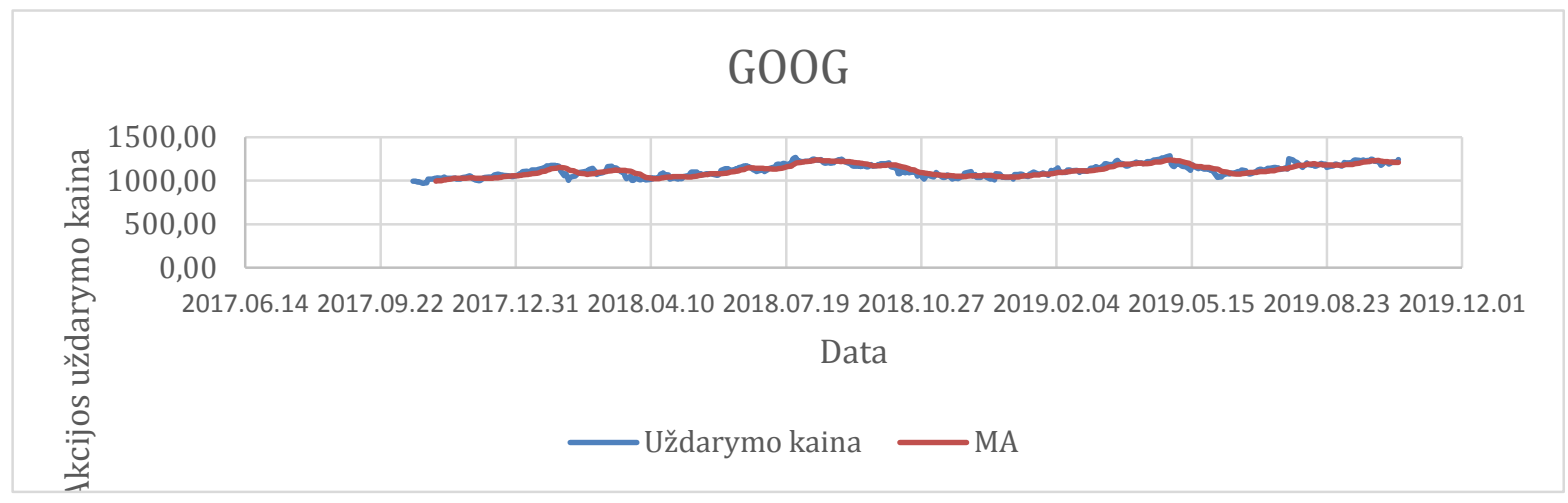

3 paveikslas. GOOGLE bendrovès akcijų kainų kitimas naudojant techninès analizès metodą (šaltinis: sudaryta darbo autorių remiantis www.finance.yahoo.com [2019.10.16] duomenimis)

3 paveiksle matoma, kad uždarymo kainos linija ir slenkančio vidurkio linija yra susikirtimo taške. Kadangi slenkančio vidurkio indikatorius rodo kritimo kryptị galima teigti, kad uždarymo kaina kris, tačiau prognozė netiksli, aiškiai neparodo. Kaina gali kristi arba kilti. Remiantis Yahoo finance duomenimis, akcijų kaina krito.

Patikrinus ir kitų likusių bendrovių (NFLX, TSLA) akcijų uždarymo kainų prognozes, slenkančio vidurkio indikatoriaus prognozès linija buvo taip pat žemiau uždarymo kainos linijos - kainos kilimas. Prognozė buvo teisinga. Taigi techninės analizès slenkančio vidurkio indikatorius visose bendrovėse rodè teisingą kryptị, tačiau kaip teorinèje dalyje pateiktoje taisyklëje, kad jei slenkančio vidurkio linija bus aukščiau - kaina kris, ir atvirkščiai, buvo matomi netikslumai GOOG ir AMZN bendrovèse.

Taip pat prognozuojant akcijų kainų kilimus, nuosmukius, laiką kada geriausia pirkti akcijas, o kada parduoti vis daugiau yra naudojamąsi dirbtinio intelekto atmainomis. Viena iš jų - MATLAB giliojo mokymosi programa, kuri tampa kaip paramos sistema investuotojui. Svarbią reikšmę giliojo mokymosi metodo naudojime daro paklaida (angl. RMSE). Tai vienas iš veiksmingiausių rodiklių, kuris matuoja skirtumus tarp stebimų verčių ir numatytų verčių (Wang et al., 2020), taip pat rodo vidutinị numatomos vertès įvertinimo paklaidos dydį, kuris apskaičiuojamas (Maqsood et al., 2020):

$$
R M S E=\sqrt{\frac{\sum_{t=} n(\text { prognoz } \dot{e}(t)-i \text { storiniai duomenys }(t))^{2}}{n}} .
$$

Taigi, paklaida parodo skirtumą tarp nagrinėjamų istorinių akcijų kainų duomenų ir kokia turejjo būti prognozuojama vertè. Todèl galima lengvai patikrinti klydimą. Šio darbo pagrindiniu tikslu lieka išsiaiškinti, ar 
giliojo mokymosi programų modeliai gali nuspèti akcijų keitimosi kryptị. Kaip ir techninëje analizèje, nagrinëjant 2 metų periodo, trijų dienų akcijų grafikų kitimą buvo analizuojami grafikai techninèje analizèje naudojamus jau pirmoje dalyje nagrinètus indikatorius bei pasirinktas bendroves.
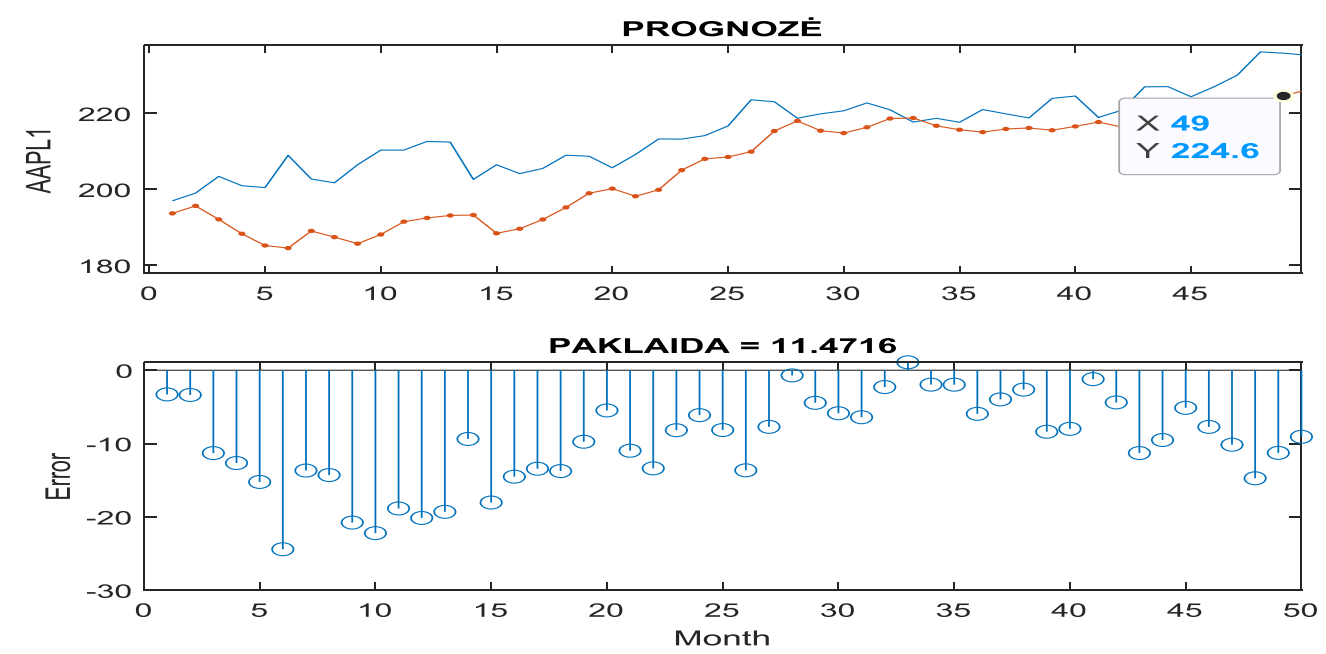

4 paveikslas. Apple bendrovės akcijų kitimo prognozè taikant giliojo mokymosi metodą (šaltinis: sudaryta darbo autorių remiantis www.finance.yahoo.com [2019.10.16] duomenimis)

4 paveiksle matoma AAPL giliojo mokymosi suformuotą grafiką. Grafiko pabaigoje prognozuojama akcijų kaina laikosi arčiau istorinių duomenų. Todèl paklaida mažeja. Paskutiniame grafiko taške, prognozės linija matoma žemiau negu suformuota pagal istorinius akcijų kainų duomenis. Tai rodo, kad akcijų kaina kils. Pačios prognozès kryptis taip pat kyla ir paklaida matoma ganėtinai žema, paklaida (angl. RMSE) - 11,47.
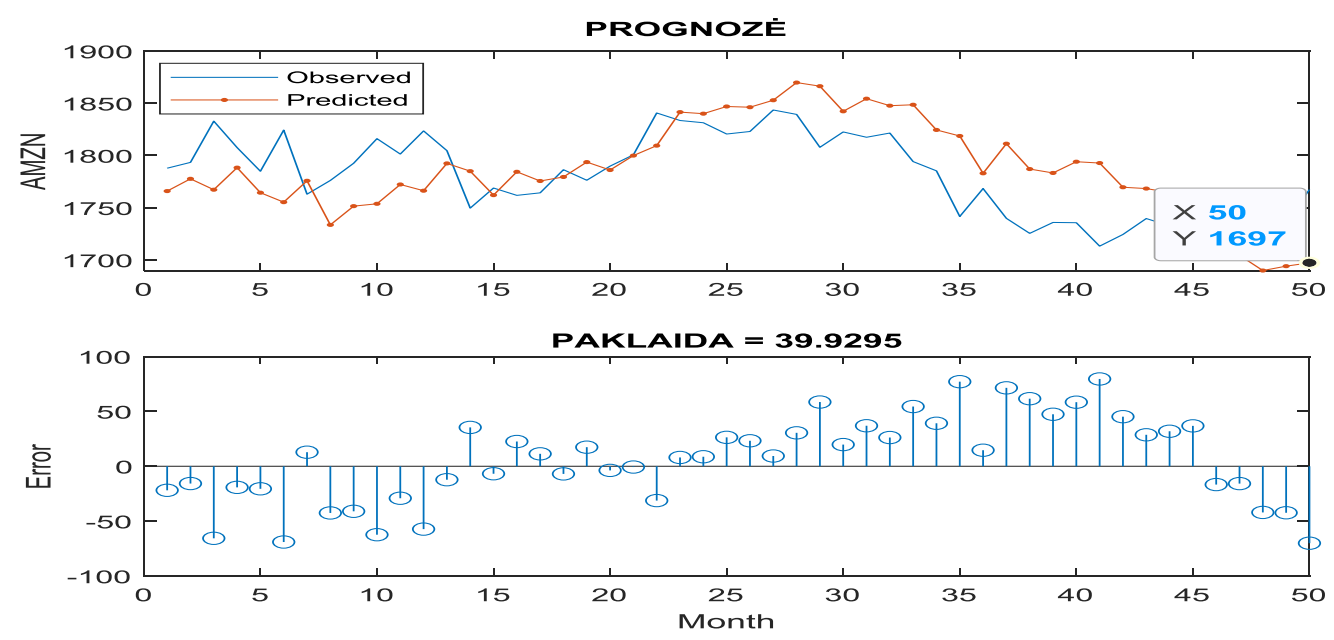

5 paveikslas. Amazon bendrovès akcijų kitimo prognozė taikant giliojo mokymosi metodą (šaltinis: sudaryta darbo autorių remiantis www.finance.yahoo.com [2019.10.16] duomenimis)

5 paveiksle matoma giliojo mokymosi būdu sudaryta AMAZON akcijų kainų kitimo prognozè. Pagal dviejų metų laikotarpyje surinktus $A M A Z O N$ akcijų kitimo duomenis, giliojo mokymosi programa, remiantis tik pateiktais duomenimis be apsimokymo, būtų nuspejjusi AMAZON akcijų kainų augimą, tačiau ịvykus giliajam mokymuisi šiame atvejyje prognozavimo linija yra stipriai žemiau negu tyrinejjami akcijų duomenis. Taip aiškiai matoma, kad akcijų kaina tikrai turètų kristi. 

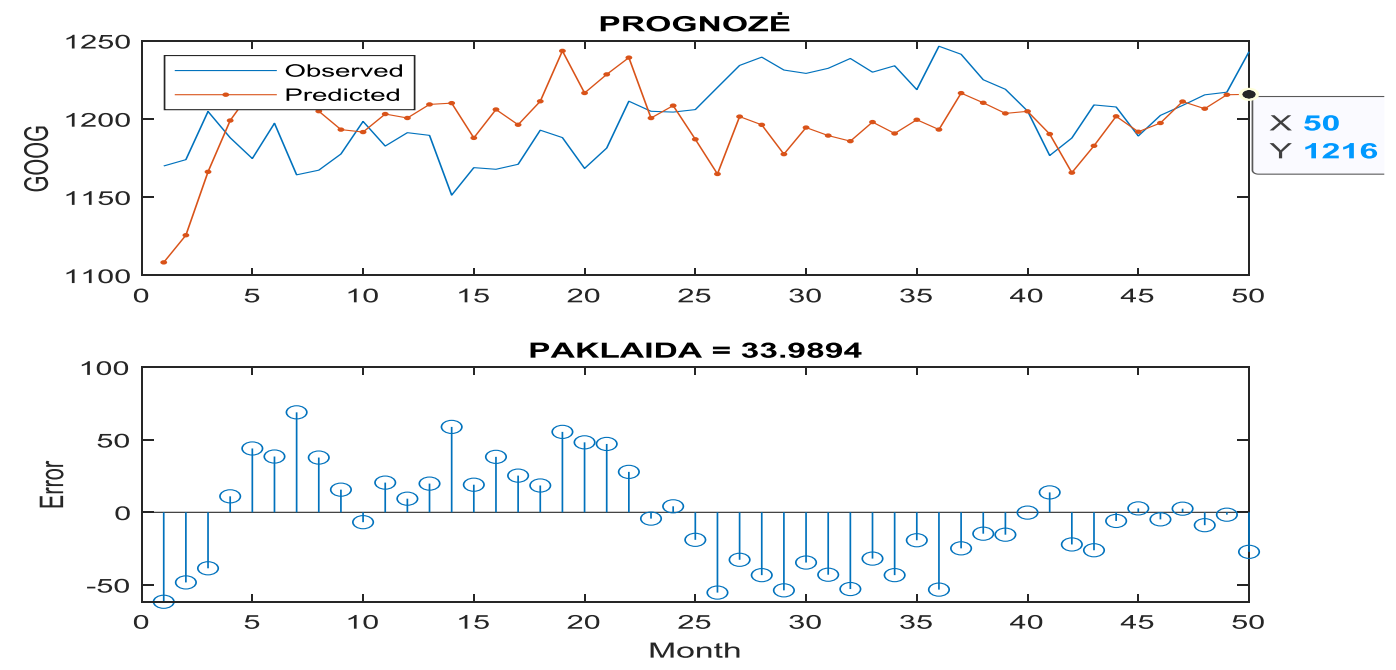

6 paveikslas. Google bendrovès akcijų kitimo prognozè taikant giliojo mokymosi metodą (šaltinis: sudaryta darbo autorių remiantis www.finance.yahoo.com [2019.10.16] duomenimis)

6 paveiksle matoma GOOG akcijų kainų krypties prognozè. Matomas netolygus akcijų kainų judejjimas. Iš paveikslo matyti trys staigūs pasikartojantys kritimai. Galutiniame taške pastebimas susikirtimo taškas, kryptis išlieka neutrali, nei leidžiasi nei kyla. Paklaida - 33,99.

\section{Investavimo akcijų rinkose modelių pritaikomumo ir tikslumo vertinimas}

Antrajame skyriuje buvo analizuoti akcijų kainų judejimo kryptys naudojant tradicinius metodus, kaip: techninès analizès metodas ir patobulintus, kaip giliojo mokymosi metodas. Atliktas praktinis tyrimas akcijų kainų prognozės nuspejjamumui, kurio metu buvo siekiama išsiaiškinti tinkamiausio metodo panaudojimą investuojant. Todèl trečiajame skyriuje, pasirinkus penkias skirtingas bendroves (Apple, Amazon, Google, Neflix ir Tesla) buvo analizuoti antroje dalyje gautų akcijų kainų grafikai ir jų kitimas.

1 lentelè. Suminè nagrinèjamų metodų lentelè (šaltinis: sudaryta darbo autorių remiantis antroje dalyje nagrinètais grafikais)

\begin{tabular}{|c|c|c|}
\hline Bendrovès & MATLAB & MA \\
\hline APPL & + & + \\
\hline AMZN & $+/-$ & $+/-$ \\
\hline GOOG & $+/-$ & $+/-$ \\
\hline NFLX & + & - \\
\hline TSLA & + & + \\
\hline
\end{tabular}

Nagrinëjant penkių pasirinktų bendrovių akcijų kitimo grafikus bei jų kryptị, pagal sudarytą 1 lentelę matoma, kad giliojo mokymosi metodas akcijų kitimo kryptị suprognozavo geriau, nors ir nežymiai. Giliojo mokymosi metodu ir techninès analizès sudarytuose grafikuose akciju judèjimo išdèstymas matomas labai panašiai. Pagal grafiką tiksliai nurodè Apple, Neflix ir Tesla įmoių akcijų judèjimo kryptị. Tuo tarpu naudojantis techninès analizès metodo slenkančio vidurkio indikatoriumi tiksliai pavyko nustatyti tik Tesla ir Apple akcijų kitimą.

2 lentelè. Giliojo mokymosi ir techninès analizès apskaičiuotos paklaidos (šaltinis: sudaryta darbo autorių remiantis antroje dalyje nagrinètais grafikais)

\begin{tabular}{|c|c|c|}
\hline & MATLAB & MA \\
\hline APPL & 11.47 (RMSE) & 16.55 (RMSE) \\
\hline AMZN & 39.9 (RMSE) & 60.41 (RMSE) \\
\hline GOOG & 33.9 (RMSE) & 32.13 (RMSE) \\
\hline NFLX & 6.41 (RMSE) & 16.55 (RMSE) \\
\hline TSLA & 9.43 (RMSE) & 17.79 (RMSE) \\
\hline
\end{tabular}


Pagal pateiktą 2 lentelę matoma, kad naudojantis giliojo mokymosi metodo programa Matlab akcijų prognozavimo paklaida buvo visur mažesnè negu prognozuojant technine analize, išskyrus tik Google bendrovę, kur paklaida mažesnè naudojant slenkančio vidurkio indikatorių.

\section{Išvados}

Investuotojui stebinčiam akcijų kainų kitimą svarbiausia yra kryptis, kadangi, jei labiausiai naudojami techninės analizès indikatoriai parodys apytikslias akcijų kainas, kurios viena nuo kitos skirsis nežymiai, tai investuojant didelès reikšmès neturès. Todèl investuotojai didžiausią dèmesị skiria prognozavimo metodų tobulinimui. Analizuojant akcijų kainų prognozes grafiškai, matoma, kad prognozė naudojant giluji mokymąsi buvo tikslesnè už prognozę naudojantis slankiojo vidurkio metodu apie 20 procentų. Todèl giliojo mokymosi metodas gali tapti puikia paramos sistema investuotojui, kuri patikslina ir nukreipia tinkama linkme tradiciniu būdu gautas akcijų kainų prognozes. Naudojant techninès analizès indikatorius ir giliojo mokymosi programas kartu, gali būti pasiekiamas tikslesnis prognozavimas, kadangi išsiskyrus krypčiai ar nesutapus prognozuojamoms akcijų kainoms galima atlikti dar gilesnę analizę, analizuojant skirtingus rodomus duomenis. Tyrimas atliktas labai trumpą laiką ir apsiribojo vienu techninès analizès indikatoriumi. Investavimo strategijos naudojant giluji mokymąsi sukūrimas, testavimas ir tyrimas gali būti tolesnè mokslinè kryptis.

\section{Literatūra}

Al-Radaideh, Q., Assaf, A., \& Alnagi, E. (2013). Predicting stock prices using data mining techniques. In The International Arab Conference on Information Technology, 1-8. http://www.acit2k.org/ACIT/2013Proceedings/163.pdf

Amilevičius, D. (2017). Dirbtinis intelektas ir besiformuojančių technologijų etika. Naujasis židinys-Aidai, (4), 19-24. https://hdl.handle.net/20.500.12259/35657

Bikas, E., \& Kavaliauskas, A. (2010). Lithuanian investors' behaviour during financial crisis. Business: Theory and Practice, 11(4), 370-380. https://doi.org/10.3846/btp.2010.40

Boreika, P. ir Pilinkus, D. (2009). Makroekonominių rodiklių ir akcijų kainų tarpusavio ryšys Baltijos šalyse [Relations between macroeconomic indices and stock prices in the Baltic countries]. Ekonomika ir vadyba, 14, $692-699$. http://search.ebscohost.com/login.aspx?direct=true\&db=bth\&AN=41976539\&site=ehost-live\&scope=site

Cervelló-Royo, R., Guijarro, F., \& Michniuk, K. (2015). Stock market trading rule based on pattern recognition and technical analysis: Forecasting the DJIA index with intraday data. Expert Systems with Applications, 42(14), 5963-5975. https://doi.org/10.1016/j.eswa.2015.03.017

Cibulskienė, D. ir Marcišauskienė, J. (2013). Baltijos šalių makroekonominių rodiklių ir akcijų rinkos kainų tarpusavio ryšio vertinimas. Ekonomika ir vadyba: aktualijos ir perspektyvos, 1(29), 51-61.

Gang, J., Qian, Z., \& Xu, T. (2019, August). Investment horizons, cash flow news, and the profitability of momentum and reversal strategies in the Chinese stock market. Economic Modelling, 83, 364-371. https://doi.org/10.1016/j.econmod.2019.08.021

Ginevičius, R. ir Podvezko, V. (2008). Daugiakriterinio vertinimo būdų suderinamumas. Verslas: teorija ir praktika, 9(1), 73-80. https://doi.org/10.3846/1648-0627.2008.9.73-80

Goertzel, B. (2014). Artificial general intelligence: Concept, state of the art, and future prospects. Journal of Artificial General Intelligence, 5(1), 1-48. https://doi.org/10.2478/jagi-2014-0001

Heaton, J. B., Polson, N. G., \& Witte, J. H. (2016). Deep learning in finance. http://arxiv.org/abs/1602.06561

Yahoo Finance. (2019). https://finance.yahoo.com/

Kekytė, I. ir Stasytytė, V. (2017). Investavimo sprendimų prièmimo modelių lyginamoji analizè. Mokslas - Lietuvos Ateitis, 9(2), 197-208. https://doi.org/10.3846/mla.2017.1023

Kresta, A., \& Franek, J. (2015). Analysis of moving average rules applicability in Czech stock market. Procedia Economics and Finance, 30(1965), 364-371. https://doi.org/10.1016/S2212-5671(15)01303-9

Lileikienè, A. ir Dervinienè, A. (2010). Akcijų portfelio formavimas ir valdymas fundamentalios ir techninès analizès pagrindu. Vadyba, 1(17), 15-24.

Maqsood, H., Mehmood, I., Maqsood, M., Yasir, M., Afzal, S., Aadil, F., Selim, M. M., \& Muhammad, K. (2020). A local and global event sentiment based efficient stock exchange forecasting using deep learning. International Journal of Information Management, 50, 432-451. https://doi.org/10.1016/j.ijinfomgt.2019.07.011

Matlab algoritmas. (2019). https://ch.mathworks.com/help/deeplearning/examples/time-series-forecasting-using-deeplearning.html

Metghalchi, M., Chang, Y.-H., \& Garza-Gomez, X. (2011). Technical analysis of the taiwanese stock market. International Journal of Economics and Finance, 4(1), 90-102. https://doi.org/10.5539/ijef.v4n1p90

Mockaitienè, S. ir Žmiejauskaitè, K. (2009). Finansų rinkų krizès priežastys ir pasekmès Pabaltijo šalių akcijų rinkai. Ekonomikos ir vadybos aktualijos, 178-188.

Naranjo, R., \& Santos, M. (2019). A fuzzy decision system for money investment in stock markets based on fuzzy candlesticks pattern recognition. Expert Systems with Applications, 133, 34-48. https://doi.org/10.1016/j.eswa.2019.05.012 
Nedzveckas, J. ir Dapkus, R. (2013). Valiutų kursų analizei ir prognozavimui naudojamų metodų testavimas. Vadyba, 22(1), $121-126$.

Pekarskienè, I. ir Pridotkienè, J. (2010). Vertybinių popierių rinkos vaidmuo ekonomikoje [Significance of stock market to an economy]. Ekonomika ir vadyba, 177-184. http://search.ebscohost.com/login.aspx?direct=true \&db=bth\&AN=53172863\&site=ehost-live \&scope=site

Picasso, A., Merello, S., Ma, Y., Oneto, L., \& Cambria, E. (2019). Technical analysis and sentiment embeddings for market trend prediction. Expert Systems with Applications, 135, 60-70. https://doi.org/10.1016/j.eswa.2019.06.014

Sobreiro, V. A., Cruz Cacique da Costa, T. R., Farias Nazário, R. T., Lima e Silva, J., Moreira, E. A., Lima Filho, M. C., Kimura, H., \& Arismendi Zambrano, J. C. (2016). The profitability of moving average trading rules in BRICS and emerging stock markets. North American Journal of Economics and Finance, 38, 86-101. https://doi.org/10.1016/j.najef.2016.08.003

Sureshkumar, K. K., \& Elango, N. M. (2012). Performance analysis of stock price prediction using artificial neural networks. Global Journal of Computer Science and Technology, 12(1).

Vaisla, K., Bhatt, K. A., \& Kumar, S. (2010). Stock market forecasting using artificial neural network and statistical technique: A comparison report. International Journal of Computer and Network Security, 2(8), 50-55.

Wang, W., Li, W., Zhang, N., \& Liu, K. (2020). Portfolio formation with preselection using deep learning from long-term financial data. Expert Systems with Applications, 143, 113042. https://doi.org/10.1016/j.eswa.2019.113042

\title{
INVESTIGATION OF INVESTMENT IN STOCK MARKET USING DEEP LEARNING MODELS
}

\author{
Nijolè MAKNICKIENĖ, Amanda URBONAVIČIŪTĖ
}

\begin{abstract}
Investing becomes an integral part of the financial world. As one market gamer encourages the launch or continuation of existing activities, the other players in the market are earning their shares. Therefore, each investor looks for the best solution, tactics and a method that will help to profitably determine the direction of the movement of shares. However, investors face difficulties in predicting stock variation forecasts. Often the chosen and used method is not an accurate forecasting tool, so investors focus on deep learning methods that become a support system for the investor. The article examines the comparison of the forecasts for the schedules received in deep learning and technical analysis methods, and the uncertainty about the predictability of share prices. The results of this work remain relevant and relevant, as studies relate to the use of a deep learning approach in investment, which is heavily analysed and investigated by researchers, and is still attempting to understand the success of its utilisation by investing.
\end{abstract}

Keywords: investing, deep-learning, technical analysis, share price, stock market, prediction, support system. 